\title{
Elementary Science in Secondary Schools
}

$\mathrm{I}^{\mathrm{N}}$ a consideration of the School Certificate Examination, the Panel of Investigators appointed by the Secondary School Examinations Council reported in 1932* that so far as science is concerned, the examination was unsatisfactory. There are fifteen possible ways that a candidate for School Certificate may be examined in science, no examining body having less than five possibilities. By taking advantage of the possibilities offered, a candidate may under some examining bodies offer for a science pass in School Certificate, either heat, light and sound, or magnetism and electricity, without any other science subject. While this is possible in only three out of the eight examining bodies, in all cases a candidate need only offer one science, usually chemistry, physics or botany, in order to pass in science. The concentration thus demanded on a single science subject in the school examination is not regarded as in the best interests of the pupil or of science, in that it is impossible to achieve any satisfactory training in scientific method by a consideration of any one single science, and that also such a procedure does not give to the pupil a sufficiently comprehensive idea of what is connoted by the term 'science'.

These disadvantages, to which the Panel of Investigation directed attention, have been realised by some examining bodies, and attempts have been made to suggest broader conceptions of science in examinational syllabuses. Thus general physics, physics cum chemistry (under various names), biology, and general science have been introduced as alternative papers. The general physies paper is a purely qualitative paper, covering superficially almost the same ground as the normal physics paper; the physics cum chemistry paper is usually resolvable into a "test on a little chemistry plus a truncated course in physics"; the biology, while obviously a better introduction to life sciences than either the single subjects of botany or zoology, is usually tested by a paper divided into two sections, one botanical and the other zoological, "with little to suggest that the paper is dealing with the phenomena of living things as a whole". The most successful has been the guneral science paper, which, however, has been subjected to the criticism of superficiality.

These particular criticisms are made by the Investigators as a corollary to their general criticism of the connexion between School Certificate and Matriculation. The original intentionst of the School Certificate Examination were to "test the results of the course of general education", and to be suitable for forms in which the average age of the pupils ranges from about 16 years to 16 years 8 months, and that "the standard for a pass will be such as may be expected from pupils of reasonable industry and ordinary intelligence in an efficient secondary school" ; and it was only intended secondarily to act as a qualifying examination for entrance to universities. There is no doubt, however, that these original intentions have become obscured, and the university entrance qualification has become predominant, Matriculation being regarded as a superior kind of School Certificate by both candidates and

* The School Certiflcate Examination. (H.M. Stationery Office, 1932.) See NATURE, 131, 217, Feb. 18, 1933.

+ Board of Education Circular 849 and subsequent circulars. employers. The Investigators note the number of students entering universities from State-aided secondary schools in England and Wales in 1930-31 as 4,132, whereas the number of candidates who qualified for matriculation in the School Certificate examinations conducted by London and the Northern Joint Board in July and December, 1931, was 11,119; in other words, considering all possibilities, not more than one in four of the pupils in State-aided schools who "matriculate actually proceed to a University". Hence arises the much condemned university domination of the secondary school curriculum.

These lines of criticism of the secondary school examinations agree with the new tendency of the secondary school to regard its pupils as potential citizens and laymen, and not necessarily as potential specialists in science or any other subject. In other words, the modern secondary school is beginning to face towards the practical world of the ordinary citizen and away from the necessarily narrow academicism of the university specialist. The secondary school curriculum is being recast to bring it in line with the requirements of intelligent laymen living in a modern world.

This broadening tendency is making itself most manifest in the school science syllabuses. Thus it was agreed at the annual meeting of the Science Masters' Association on January 4 "That there is a general body of scientific knowledge not confined to either of the special fields of the physical and biological science which ought to be known both by the ordinary citizen and by those who may ultimately specialise in some corner of one of these two fields". This broader aspect of science is being termed 'Elementary Science' in order to avoid confusion with existing syllabuses designated 'General Science' and 'General Elementary Science', which, although an approach in the required direction, suffer from certain defects, criticisms, and traditions that it is hoped 'Elementary Science' may avoid.

A sub-committee of the Science Masters' Association in a recent report, defines 'Elementary Science' as "a method of presenting the fundamental principles of science based on the interpretation to youth of the world in which he lives, involving not only an understanding of these fundamental principles, but also of the attitude and method of science generally. Science is here regarded as a living whole, comprehending all the sectional sciences necessary to give youth an intelligent understanding of his biological, chemical and physical surroundings".

It is emphasised that the value of such science to the pupil lies not only in a wide appreciation of his biological, chemical and physical environment, but also in an understanding of the characteristic attitude and methods of the scientific worker. Moreover, 'Elementary Science' places the needs of the pupils before the demands of any sectional science; its essence lies not so much in the syllabus, the content of which must be selected and organised according to the actual environment and needs of the pupils, as in the interpretation of it as a method of explaining that environment. Its content must, of course, include the three fundamental sciences of biology, chemistry and physics, but the proportions of each are determined not by their relative importance as 
sciences, but by the extent to which they each contribute to the environment.

In order to meet the criticism of superficiality and triviality to which all broad schemes of science teaching are subject, the sub-committee referred to has drawn up not only a suggested syllabus, but also a list of fundamental principles of science, the application of which is of fundamental importance in the life of the ordinary citizen, and towards a knowledge of which it is felt that any course of elementary science, whatever its content, should aim. These fundamental principles presented as the aims of the new subject need, and it is hoped will get, criticism and correction by scientific workers, laymen and all interested in educational matters.

It is realised, too, that there are many practical difficulties of method, organisation and teaching, particularly where teachers are by their training of necessity specialists ; but it is felt that with a clear statement of aim and policy, these difficulties will not be insuperable.

What is more controversial is the recommendation of the Investigators, which was agreed to by the Science Masters' Association at the annual general meeting, to make an examination in this subject of elementary science compulsory for all School Certificate candidates, unless they offer all three science subjects, biology, chemistry, physics. But it is felt that, while no brief is held for examinations, as such, so long as they exist they do largely influence the curriculum of the schools, and unless the subject of elementary science, like English and mathematics, is made compulsory, it will not receive serious consideration in competition with other subjects of examinational value. Moreover, much as compulsion is disliked, it is pointed out that compulsion for the science candidate virtually exists at the moment, but confined to a very narrow field of one science, or part of one science. The result of the adoption of compulsory elementary science in School Certificate would broaden both the examination and the school curriculum and thus be of most benefit to what, after all, should be the paramount consideration-the needs of the ordinary pupil.

F. W. TURNER.

\section{Patents and Inventions}

$\mathrm{T}$ HE Institution of Mechanical Engineers has recently formed an Inventions Advisory Committee with Mr. W. Taylor as chairman. In connexion with the inauguration of this Committee, on January 26 a meeting of the Institution was held when four short papers were read dealing with invention and inventors. These papers were "The Evolution of Invention", by H. W. Dickinson; "The Inventor", by Dr. H. S. Hatfield; "Provisional Patent Protection and Patent Claims", by Sir William Jarratt and "The Development and Exploitation of Inventions", by A. H. Gledhill.

The subject is a vast one, for as Mr. Dickinson said, "All social, economic, physical, technical, and commercial developments are the result of invention, and we may say that civilization is a synthesis of the inventions made by man since his appearance on this planet a million years ago". The word invention to-day has three meanings : (1) the thing schemed or contrived; (2) the mental processes involved; and (3) the ability to evolve the new scheme or contrivance, commonly called inventiveness. As regards the encouragement of invention, England furnishes the first known instance of encouragement being given to the producer of a new process, for in 1440 (18, Henry VI) Letters Patent were granted by the Crown to John of Schiedam and his company for a method or process of manufacturing salt. It was, however, the Statue of Monopolies of 1624 which formed the basis of our present patent systems.

Dr. Hatfield seems to consider the technical inventor to be a new figure in the history of mankind, but it is doubtful whether this view is correct. The ships, the aqueducts, the tunnels and the buildings of the Romans were the result of the accumulated inventions of the day, and these would have undoubtedly been followed by others had not the Empire been overwhelmed by the barbarians of the north. In concluding his contribution to the symposium, Dr. Hatfield attempted to define the mental characteristics which distinguish the successful inventor.

While the papers of Mr. Dickinson and Dr. Hatfield referred largely to the philosophy of invention, those by Sir William Jarratt and Mr. Gledhill discussed the position of the inventor and of patent legislation to-day. Sir William Jarratt congratulated the Institution on the formation of a Standing Committee to consider inventions submitted by members. Some years ago, he said, he served on a com. mittee appointed to consider the best method of dealing with inventions made by Government servants, and through the report of that committee each of the great Departments of State has now an Awards Cormmittee, with power to recommend monetary awards for inventors. If industry in Great Britain is to maintain and improve its position in the world, it will be necessary that discovery and invention shall continue to be encouraged by public and private benevolence, by research scholarships, by a sound system of patents and by the work of committees such as that of the Institution of Mechanical Engineers.

The last paper, that by Mr. Gledhill, dealt concisely with the commercial development of inventions, the sale of the products of an invention and the manufacturing of the product of an invention. Incidentally, he mentioned that the Patent Office made a net profit of $£ 146,000$ last year, and he suggested that a portion of this might wisely be used to encourage developments of inventions which would benefit the country. It might also be proposed that some of this profit be used to improve the conditions under which the examiners work and for the upkeep of the library, where many books are in need of rebinding and where a system of vacuum cleaning would be advantageous. It may indeed be doubted whether an increase in the facilities for inventors and a reduction of their fees is not a sounder national policy than to look to the Patent Office as a source of revenue.

That there is a need for a continual revision of the patent laws was suggested by several of those who took part in the discussion of the papers. The general interest shown in the discussion is a good augury for a new departure of the Institution, which as the chairman, Col. A. E. Davidson, said, is justified by its Royal Charter, which states that one object of the Institution is "to encourage invention and research in matters connected with mechanical engineering". 